\section{Congress vows to contest 'unacceptable' NIH plans}

[WASHINGTON] Biomedical lobbyists are disappointed that President Clinton's budget proposals for 1998 would increase funding for the US National Institutes of Health (NIH) by 2.6 per cent, only slightly higher than the anticipated level of inflation.

If approved by Congress at this level, the result would be to raise NIH funding by $\$ 337$ million, to $\$ 13.1$ billion, with 80 per cent of the new money going to research project grants. The increase is substantially less than the 6.9 per cent and 5.7 per cent increases that Congress granted in 1997 and 1996 respectively. It is also slightly less than the 3.1 per cent 'biomedical inflation' rate in 1998 as calculated by the agency.

Nevertheless such an increase would enable NIH research project grants to reach a historic high, with 26,679 grants, a 3.6 per cent increase over 1997.

The budget includes $\$ 90$ million for continued construction of a \$310-million, 250-bed Clinical Research Center at the NIH in Bethesda, Maryland. It also boosts funding for the National Institute on Drug Abuse by 9 per cent - proportionately far more than other institutes - to $\$ 358$ million. The new money will be targeted at developing medication for cocaine addiction.

Donna Shalala, Secretary of Health and Human Services, said last week of the 2.6 per cent increase: "Is it enough? The answer is 'no'" But she insisted that biomedical research is a "priority" and said the modest

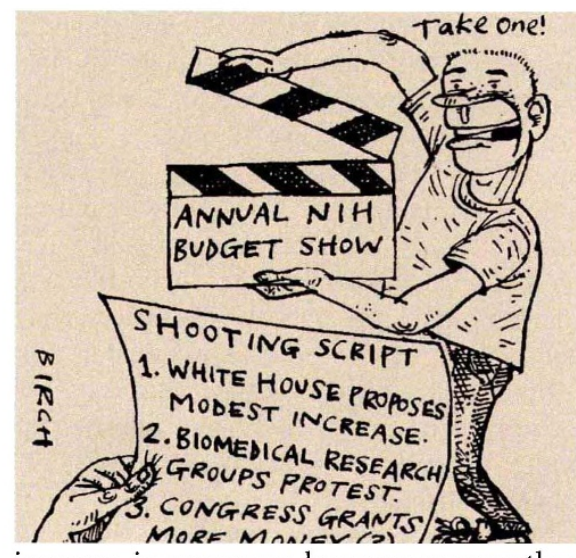

increase is necessary because many other programmes also depend on the huge department's roughly $\$ 35$-billion budget for non-mandatory expenditures.

NIH's director, Harold Varmus, said the increase would allow the agency to "maintain [its] momentum". "It's a budget I can defend" to Congress, he said. Varmus said that healthy increases over the past two years, combined with a lower than expected rate of biomedical inflation, mitigate the impact of the modest increase. Inflationary increases for continuing grants will be held to 2 per cent, and research management and support will be kept at this year's level.

The overall increase drew loud complaints from biomedical research advocates. John Suttie, president of the Federation of Societies for Experimental Biology and a biochemist at the University of Wisconsin, Madison, said: "What the NIH budget needs is continued inflationary adjustment, and then some meaningful increase."

Congressman John Porter (Republican, Illinois), chairman of the House of Representatives appropriations subcommittee that funds NIH, called the proposed 2.6 per cent overall increase "unacceptable". He said that recent statements by Clinton strongly supporting biomedical research were inconsistent with his budget. "If the president is going to talk about the importance of research, his budget ought to reflect that as a priority."

In his State of the Union speech last week, Clinton said: "We must reinforce our commitment to medical science." He called $\mathrm{NIH}$ "the most powerful discovery engine for an AIDS vaccine" and boasted that under his administration AIDS funding at the agency has increased "dramatically". The budget calls for $\$ 1.54$ billion for AIDS research in 1998, a 2.6 per cent increase over 1997, and a 44 per cent increase over 1993.

Within this, the budget for vaccine research will increase by 13 per cent, to $\$ 148$ million. "We feel there's greater potential now for thinking constructively about vaccines," Varmus said. The president's budget channels all AIDS money through the Office of AIDS Research, a policy that congressional Republicans oppose.

The Centers for Disease Control and Prevention, based in Atlanta, would receive $\$ 2.3$ billion, a 0.6 per cent increase. A programme dealing with emerging infectious diseases would receive a \$15-million increase, aimed in part at epidemiological and laboratory research. Meredith Wadman

\title{
Despite cutbacks, NASA pulls out of a threatened long-term nosedive
}

[WASHINGTON] Although the US National Aeronautics and Space Administration (NASA) is not scheduled for an increase in the proposed 1998 federal budget, it has been spared the steep decline in its long-term funding that was threatened last year. A relieved NASA administrator Daniel Goldin, said last week: "1 hoped we could do better" than last year's projection. " am happy to report we have."

Instead of seeing its funding drop below $\$ 12$ billion in the next decade, as the White House had forecast a year ago, NASA is asking for $\$ 13.5$ billion for 1998 , a total which is only slightly less than this year's final appropriation of $\$ 13.7$ billion. The agency now anticipates putting in a request for $\$ 13.4$ billion for 1999 , and $\$ 13.2$ billion for fiscal years 2000 to 2002

The agency is seeking \$2 billion for space science including astronomy and planetary exploration - in 1998 about the same as it received this year. The request for life sciences and microgravity sciences falls by 12 per cent, to $\$ 214$ million. In contrast, Earth science, including the agency's Earth Observing System satellites, increases by 4 per cent to $\$ 1.4$ billion.

The improved long-term budget picture will allow NASA to proceed with several new initiatives, including the Space Infrared Telescope Facility and an average boost of $\$ 50$ million a year for spacecraft technology development, which will push the schedule for a Mars sample return mission forward to 2005.

Additional technology spending in the next few years will also allow spacecraft missions to Pluto and Jupiter's moon Europa. Wesley Huntress, head of science atNASA, says that one of the two will be selected for funding from the beginning of 2000 .

The agency also kicks off its new 'Origins' programme in 1998 , which includes a wide range of projects from the infrared telescope to basic research in extraterrestrial biology. These and other new science initiatives will be financed largely through savings in the space shuttle programme and agency overheads, spending on both of which will continue to decline. Funding for the space station remains capped at about $\$ 2$. billion a year.

The higher five-year budget projections have killed interest in a 'space summit' meeting between the White House and Congress to decide NASA's long-term spending outlook (see Nature 384 610; 1996). Goldin credits Senator Barbara Mikulski (Democrat, Maryland), who called for the summit meeting last year, with forcing the Clinton administration to re-evaluate its projections for the agency.

The new chairman of the House of Representatives Science committee, James Sensenbrenner (Republican, Wisconsin) said last week he thought the summit would be a "waste of time" until questions about the space station are resolved. 